Special Issue: Agricultural Productivity and Sustainability Improvement in Tropical Region

\title{
Enhanced of Root Nodules, Uptake NPK, and Yield of Peanut Plant (Arachis hypogaea L.) using Rhizobium and Mycorrhizae Applications
}

\author{
Praptiningsih Gamawati Adinurani, ${ }^{1 *}$, Sri Rahayu ${ }^{1}$, Endang Dwi Purbajanti ${ }^{2}$, Devi Dwi Siskawardani ${ }^{3}$, \\ Karina Stankeviča ${ }^{4}$ and Roy Hendroko Setyobudi ${ }^{5}$
}

${ }^{1}$ Department Agrotechnology, Faculty of Agriculture, Merdeka University of Madiun, Jl. Serayu No.79, Madiun 63133, East Java, Indonesia; ${ }^{2}$ Department Agriculture, Faculty of Animal and Agricultural Sciences, Diponegoro University, Jl. Prof Sudharto SH, Tembalang, Semarang 50275, Central Java, Indonesia; ${ }^{3}$ Department of Food Technology, Faculty of Agriculture and Animal Science, University of Muhammadiyah Malang, Jl. Raya Tlogomas No 246, Malang 65144 Indonesia; ${ }^{4}$ Department of Environmental Science, University of Latvia, Raina Blvd. 19, Riga LV-1050, Latvia; ${ }^{5}$ Department of Agriculture Science, Postgraduate Program, University of Muhammadiyah Malang, Jl. Raya Tlogomas No 246, Malang 65144, East Java, Indonesia.

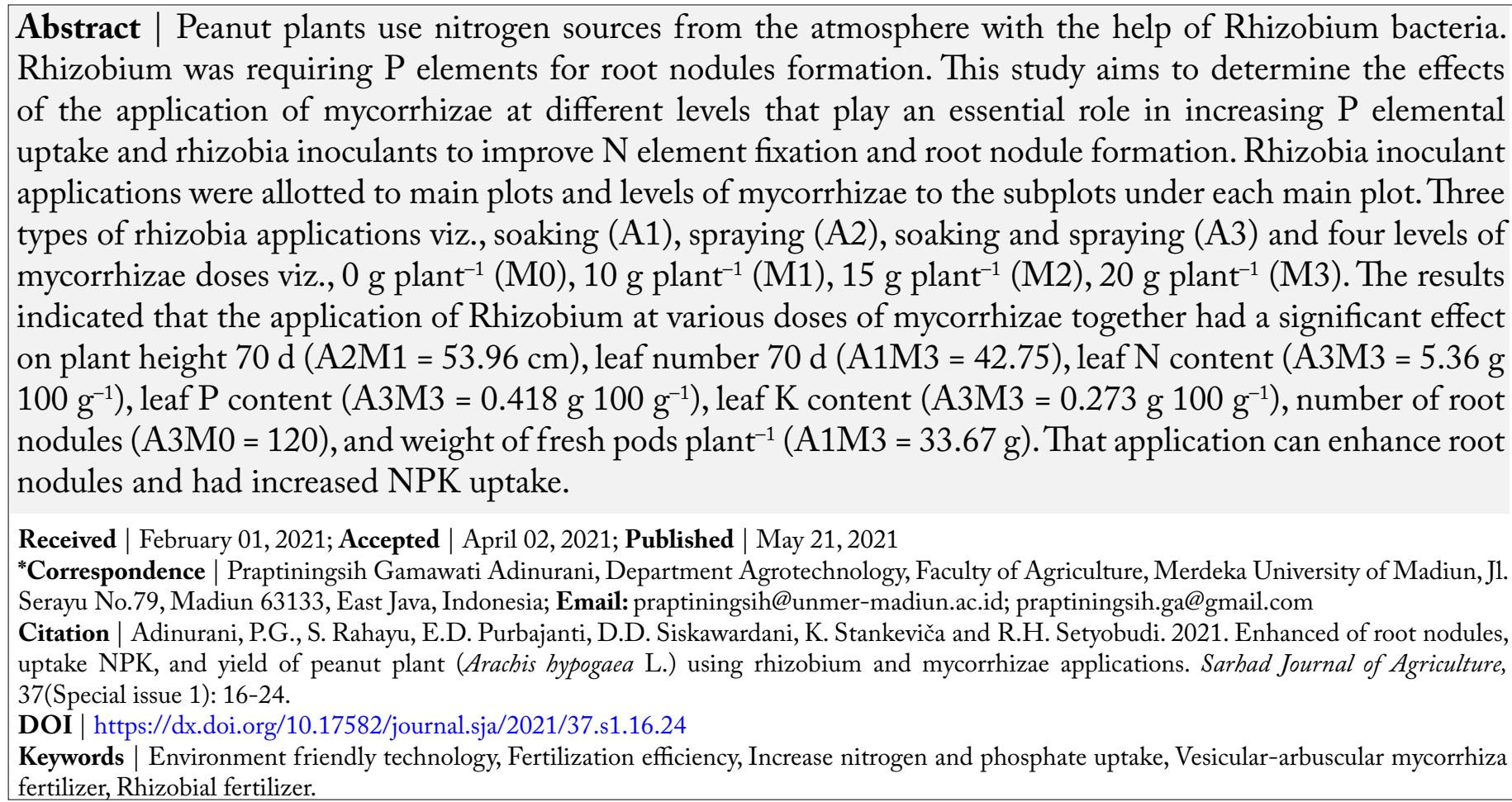

\section{Introduction}

$\mathrm{P}$ eanut (Arachis hypogaea L.) is grown in more than 100 countries over $22 \times 10^{6}$ ha in the tropical and sub-tropical countries (Ahmed et al., 2016). Peanut productivity in tropical countries, including Indonesia, India, and countries in Africa, is generally almost the same, between (0.7 to 1.3) tha ${ }^{-1}$ of dry pods (Sumarno,
2015). Kementerian Pertanian (2017) reports that productivity of peanuts has fluctuated throughout 5 year in the period 2013 to 2017 with the average productivity of $1.318 \mathrm{t} \mathrm{ha}^{-1}$. Peanut productivity in Indonesia is relatively low, compared to USA, China, Australia and Argentina, which have reached more than 2 t ha $^{-1}$ (Kurniawan et al., 2017; Sumarno, 2015). The efforts to increase peanut production are carried 
out by improving the formation of root nodules. Phosphorus plays an essential role in the development of root nodules. Peanut plants need essential nutrients such as $\mathrm{N}, \mathrm{P}$ and $\mathrm{K}$. Legume plants are provided with natural potential for atmospheric nitrogen fixation when associated with a suitable microbial partner, rhizobia (Rehman et al., 2019).

Nitrogen $(\mathrm{N})$ is an essential nutrient for the growth of peanut plants, but $\mathrm{N}$ availability in tropical regions such as Indonesia is relatively low (Budiono et al, 2019). Nitrogen, which forms a protein compound, cannot be used directly by plants, although in the atmosphere, there is $\mathrm{N}_{2}$ around $80 \%$. Nitrogen nutrients can enter the plant in the form of nitrat (NO3-) and ammonium (NH4+) and amino acids (Purbajanti et al., 2019). Among the soil bacteria a unique group called Rhizobia has a beneficial effect on the growth of plants. It can live either in the soil or within the root nodules of host legumes (Kukkamalla and Vardhan, 2016).

The symbiosis between peanut plants and Rhizobium is a major ecological process in the nitrogen cycle. This symbiosis allows peanut plants to colonize $\mathrm{N}$-limited environments (Bouznif et al., 2019). The nitrogen source in the soil, the longer becomes insufficient for plant needs. Nitrogen needs can source from $\mathrm{N}$ fertilizer and $\mathrm{N}_{2}$ fixation from the atmosphere. The nitrogen is derived from their association with symbiotic rhizobia that fix atmospheric nitrogen gas into ammonia. The symbiotic nitrogen fixation has been purported to facilitate legume colonization (Simonsen, 2017). Peanuts have a high nitrogen fixation capacity. The $\mathrm{N}$ element obtained by nitrogen fixation is a cheap source and can help reduce production costs. Rhizobium inoculation to peanut can increase nitrogen fixation. Peanut can form root nodule by fast-growing rhizobia such as Rbizobium giardini and Rbizobium tropic (Taurian et al., 2006). Rhizobium, as an inoculant, can produce effective root nodules in peanut plants. Rhizobia may promote plant growth through nitrogen fixation. Anteneh (2017) found that inoculation of Bradyrbizobium is necessary to improve root nodule and seed yields.

Mycorrhizae is a type of soil microbe that can have a symbiosis with plants. It has an essential contribution to soil fertility by increasing plants' ability to absorb nutrients; especially P. Mycelium mycorrhizae can extend to areas outside the rhizosphere and enlarge the root area to absorb nutrients. Mycorrhizal colonization in plant roots can expand the absorption area of the roots with the presence of external hyphae which grow and develop through plant root feathers (Muhammad et al., 2020; Sukmawati et al., 2020). Therefore, water and nutrients can be transported by hyphae tissue to be absorbed by plants (Abd-Alla et al., 2014; Yaseen et al., 2016).

The research is planned to evaluate the beneficial effect dual inoculation of Rhizobium and mycorrhizal on increased root nodule formation and NPK uptake and peanut production.

\section{Materials and Methods}

The field work was conducted in 2018 during the dry season (mid-May through August) on the rainfed fields located at Bolosingo Village, Pacitan District, Pacitan Regency, Indonesia. The location geographically situated at an altitude of $50 \mathrm{~m}$ above sea level. Total rainfall at this location is approximately $250 \mathrm{~mm}$ year $^{-1}$ and an average maximum daily temperature was varied between $24^{\circ} \mathrm{C}$ to $28^{\circ} \mathrm{C}$. The soil's chemical properties in the experiment area were analyzed ( $\mathrm{Ta}-$ ble 1) as an illustration of the initial soil conditions.

Table 1: Initial soil chemical properties.

\begin{tabular}{|c|c|}
\hline Soil chemical properties & Initial soil \\
\hline $\mathrm{pH}\left(\mathrm{H}_{2} \mathrm{O}\right)$ & 5.640 \\
\hline Organic-C ( \%) & 2.377 \\
\hline Organic Matter ( \%) & 3.087 \\
\hline Total N (\%) & 0.179 \\
\hline $\mathrm{C} / \mathrm{N}$ ratio & 13.265 \\
\hline Total $\mathrm{P}_{2} \mathrm{O}_{5}\left(\mathrm{mg} 100 \mathrm{~g}^{-1}\right)$ & 16.333 \\
\hline $\mathrm{P}_{2} \mathrm{O}_{5}$ Bray $\left(\mathrm{mg} 100 \mathrm{~g}^{-1}\right)$ & 6.634 \\
\hline Total $\mathrm{K}_{2} \mathrm{O} \mathrm{HCl} 25 \%\left(\mathrm{mg} 100 \mathrm{~g}^{-1}\right)$ & 13.099 \\
\hline
\end{tabular}

Field experiment started with the ploughing process to homogenize the soil quality. Hoeing and ploughing the land two times to obtain loose soil. There were 36 plots with a size of $(2.5 \times 3) \mathrm{m}$ each to accommodate the number of treatments and three replications.

The cultivar of peanut plant used is Kelinci. The application of mycorrhizae doses using "mikoriza plus" (solid commercial biofertilizer, CV Wahana Sukses, Malang, Indonesia) contains mycorrhizal plus Trichoderma sp., Bacillus subtilis, and Pseudomonas fuorescent. Mycorrhizae fertilizer dose was applied 
at planting. The application of Rhizobium using "Legume" (commercial liquid biofertilizer, PT Central Biotech Indonesia) that contain Rhizobium and Phosphorus Solubilizing Bacteria (PSB). It was soaking the seeds in a "Legume" biofertilizer solution with a concentration of $30 \mathrm{~mL} \mathrm{~L}^{-1}$ within (10 to 15) sec and it is executed before planting. Spraying biofertilizers is carried out on plants aged $25 \mathrm{~d}$ and $45 \mathrm{~d}$ after planting with a concentration of $2 \mathrm{~mL} \mathrm{~L}^{-1}$.

The study used split plot design which was repeated three times with the application factor of Rhizobium (A) occupying the main plot consisting of soaking (A1), spraying (A2), soaking and spraying (A3). The factor of mycorrhizae fertilizer dose per plant (M) allocated to the subplots consisted of $0 \mathrm{~g}$ (M0), $10 \mathrm{~g}$ (M1), $15 \mathrm{~g}$ (M2), and $20 \mathrm{~g}$ (M3)). Observations were made on growth and yield variables including plant height, number of branches, leaf area index, levels of $\mathrm{N}, \mathrm{P}, \mathrm{K}$ leaves, number of root nodules, the weight of root nodules, number of pods per plant, and weight of pods per plant.

Data collected about nodule formation, NPK uptake, growth and production parameters were statistically analysed using SPSS 25.0. The treatment means were compared using analysis of variance technique, followed by Duncan's Multiple Range Test (DMRT) at $5 \%$ of probability level $(\mathrm{p}<0.05)$.

\section{Results and Discussion}

\section{Nodule formation}

The number of root nodules per plant was significantly different on the application of Rhizobium in various doses of mycorrhizae (Fig. 1) whereas the weight of nodules was not affected by both of treat applied, but the percentage of effective root nodules was difference significantly on doses of mycorrhizae (Table 2).

The number of root nodules formed varied not along with the increase in mycorrhizae dose given (Fig. 1). The forming of root nodules increased at first then decreased in $20 \mathrm{~g}$ mycorrhizae dose combined with the application of soaked Rhizobium (A1M3) and sprayed (A2M3). On the other hand, declined in the beginning then increased at a dose of mycorrhizae $20 \mathrm{~g}$ combine with Rhizobium soak and spray (A3M3). Peanut seed that soaked with Rhizobium and planted directly will occur mortality of Rhizobium bacteria since have to adjust to the environmental conditions of the soil until the seeds germinate and form roots.

The formation of roots helps the Rhizobium to colonize and infect the roots so that the Rhizobium mortality rate decreases. Likewise, the occurrence of mycorrhizal infections in the roots of peanut plants can increase the tolerance of plants to drought, so that the amount of Rhizobium can develop and have an impact on the formation of root nodules and nitrogen fixation (Meng et al., 2015).

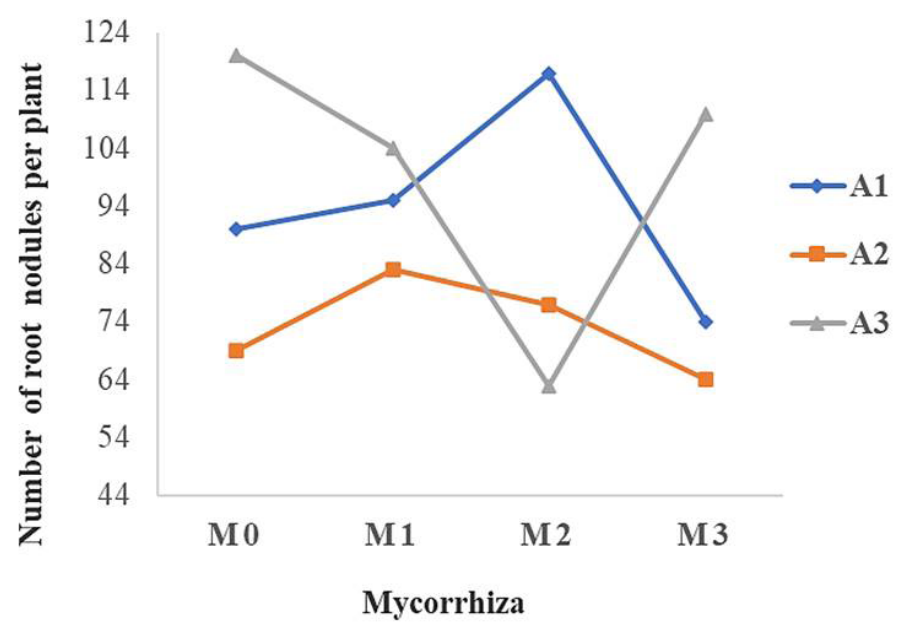

Figure 1: Interaction between the application of Rhizobium and mycorrbizae doses to number of root nodules per plant.

Table 2: Percentage of effective nodules and root nodules weight per plant at Rbizobium application and various doses of mycorrhizae.

\begin{tabular}{|lcc|} 
Treatment & $\begin{array}{c}\text { Effective root } \\
\text { nodules (\%) }\end{array}$ & $\begin{array}{c}\text { Weight root } \\
\text { nodules (g) }\end{array}$ \\
\hline A1 & 86.25 & 3.54 \\
A2 & 81.25 & 0.83 \\
A3 & 80 & 1.72 \\
& $\mathrm{~ns}$ & $\mathrm{~ns}$ \\
M0 & $76.67 \mathrm{a}$ & 2.08 \\
M1 & $80.00 \mathrm{a}$ & 2.01 \\
M2 & $83.33 \mathrm{ab}$ & 1.95 \\
M3 & $90.00 \mathrm{~b}$ & 2.08 \\
& & $\mathrm{~ns}$ \\
\hline
\end{tabular}

Means followed by the same letter within the same column are not significantly different at DMRT $5 \%$.

The existence of the Rhizobium indigenous population can help the treatment of Rhizobium spray application. However, if the community is large, it will inhibit the rhizobia inoculant applied (Chemining'wa et al., 2011). This is indicated by the application of Rhizobium spray at various doses of 
mycorrhizae which produce the lowest number of root nodules.

Rhizobium inoculation in peanut plants is not only affected by the method of application but many factors influence. The physical, chemical and biological conditions of the soil determine the effectiveness of the symbiotic relationship between Rhizobium bacteria and their host plants. Similarly, the quality of inoculants applied. In the infection phase, Rhizobium actively grows and divides itself so that it is highly dependent on the availability of nutrients outside of plant cells. Therefore, the lack of essential nutrients when the infection phase can limit the formation of root nodules.

It can be seen in Table 2, the Rhizobium application has no significant influence on effective root nodules and weight of nodules. However, the soak application (A1) is the highest $86.25 \%$ and $3.54 \mathrm{~g}$, respectively. In otherwise, the mycorrhizae dose has significantly different. The effective nodules varied from (76.67 to 90.00) \%. Maximum effective nodules were recorded under treatment $20 \mathrm{~g}$ (M3) and minimum with without mycorrhizae $0 \mathrm{~g}$ (M0). Without mycorrhizae, nutrient uptake is only at the tip of the hair root and the nutrients absorbed are only in the available form. While mycorrhizal fertilizer was added with mycorrhizal hyphae which grew widely with plant root tissue. Nutrients absorbed by tissue hyphae are brought to the tips of root hairs to be exchanged with polysaccharides. The level of hyphae in absorbing nutrients is much broader than root tissue without mycorrhizae (Adinurani et al., 2019; Marzban et al., 2017).

The effective nodule percentage indicates that Rhizobium actively fixation nitrogen. The more percentage of the nodule effective shows the more nitrogen is tethered. According to Labidi et al. (2015), Suryantini (2015) that an effective symbiotic relationship can be identified by cut the nodule in the initial period of flowering, and observing the color. Effective root spots are large and have a bright red color on the inside. Red pigment is leghemoglobin which shows active nitrogen fixation.

\section{NPK uptake}

$\mathrm{N}, \mathrm{P}$, and $\mathrm{K}$ elements of the leaves of peanut plants were significantly affected by the application of Rhizobium to the administration of various doses of mycorrhizae (Table 3).
The data in Table 3 shows the trend of increasing $\mathrm{N}$, $\mathrm{P}$ and $\mathrm{K}$ uptake in leaves as the doses of mycorrhizae increase. The symbiosis of mycorrhizae with plant roots has an essential role in plant growth, both ecologically and agronomically. These roles include increasing $\mathrm{P}$ uptake and other nutrients, such as $\mathrm{N}$, $\mathrm{K}, \mathrm{Zn}, \mathrm{Cu}, \mathrm{Mn}$, and $\mathrm{Mg}$ in the soil (Ortas, 2010; Mukhongo et al., 2017). In this research, the highest absorption of $\mathrm{N}, \mathrm{P}$ and $\mathrm{K}$ in leaves was achieved by application of the spray soak Rhizobium together with $20 \mathrm{~g}$ of mycorrhizae (A3M3). The highest plant nutrient uptake occurs when the plant reaches its maximum vegetative point (Utami et al., 2020). Nitrogen-fixing activity in peanut plants starts at 2530 days of age and reaches a maximum near the end of the plant growth phase.

Table 3: The levels of N, $P$ and $K$ elements of peanut plant leaves as an influence from the application of Rhizobium at various doses of mycorrhizae.

$\begin{array}{lccc}\text { Treatment } & \mathbf{N}\left(\mathbf{g} \mathbf{~ 1 0 0 ~} \mathbf{g}^{-1}\right) & \mathbf{P}\left(\mathbf{g} \mathbf{1 0 0 ~ \mathbf { g } ^ { - 1 }}\right) & \mathbf{K}\left(\mathbf{g} \mathbf{1 0 0 ~ \mathbf { ~ } ^ { - 1 }}\right) \\ \text { A1M0 } & 3.19 \mathrm{a} & 0.366 \mathrm{a} & 0.231 \mathrm{a} \\ \text { A1M1 } & 3.75 \mathrm{~cd} & 0.376 \mathrm{~d} & 0.238 \mathrm{c} \\ \text { A1M2 } & 3.81 \mathrm{~d} & 0.384 \mathrm{e} & 0.241 \mathrm{~d} \\ \text { A1M3 } & 4.16 \mathrm{e} & 0.394 \mathrm{~g} & 0.244 \mathrm{e} \\ \text { A2M0 } & 3.35 \mathrm{ab} & 0.371 \mathrm{~b} & 0.232 \mathrm{~b} \\ \text { A2M1 } & 4.31 \mathrm{e} & 0.386 \mathrm{f} & 0.254 \mathrm{f} \\ \text { A2M2 } & 4.37 \mathrm{e} & 0.394 \mathrm{~g} & 0.256 \mathrm{~g} \\ \text { A2M3 } & 4.73 \mathrm{f} & 0.405 \mathrm{i} & 0.259 \mathrm{~h} \\ \text { A3M0 } & 3.54 \mathrm{bc} & 0.373 \mathrm{c} & 0.233 \mathrm{~b} \\ \text { A3M1 } & 4.93 \mathrm{fg} & 0.399 \mathrm{~h} & 0.267 \mathrm{i} \\ \text { A3M2 } & 4.99 \mathrm{~g} & 0.407 \mathrm{i} & 0.270 \mathrm{j} \\ \text { A3M3 } & 5.36 \mathrm{~h} & 0.418 \mathrm{j} & 0.273 \mathrm{k}\end{array}$

Means followed by the same letter within the same column are not significantly different at DMRT $5 \%$.

Peanut plants really need $\mathrm{N}$ and $\mathrm{P}$ elements. Phosphorus is required for nodule formation and nodule activity in maximum. Therefore, plants that obtain nitrogen symbiotically require more Phosphorus in number than plants fed $\mathrm{N}$ fertilizer. Inoculation of Rhizobium together with mycorrhizae has a synergistic effect on root nodule formation and nitrogen fixation. Based on research by Yakubu et al. (2010) that administering $P$ fertilizer as much as $40 \mathrm{~kg}$ $\mathrm{P}_{2} \mathrm{O}_{5} \mathrm{ha}^{-1}$ increased the number of root nodules and the number of fixated $\mathrm{N}$ was $169 \%$ compared to controls.

\section{Growth parameters}

The statistically significant interaction between Rhizobium application and a dose of mycorrhizae 
were found in the height of plant (Fig. 1) and number of leaf (Fig. 2) on $70 \mathrm{~d}$ after planting (DAP).

It can be seen in Figure 2 that the treatment of Rhizobium by soaking and spray applied with $10 \mathrm{~g}$ of mycorrhizae (A3M1) encourages the best plant growth because it produces the highest peanut plants $(53.96 \mathrm{~cm})$, although statistically not significantly different from the treatment of Rhizobium soak spray without mycorrhizae (A3M0), the application of rhizobium spray with $20 \mathrm{~g}$ of mycorrhiza (A2M3) and with $10 \mathrm{~g}$ of mycorrhizae (A2M1). The same study states that Rhizobium inoculation is capable of spurring plant heights, improving nodulation, plant growth and yield (Kurniaty et al., 2013; Malinda et al., 2019). Spraying Rhizobium on peanut plants without fertilization gave the best growth response to all observed variables (Prayoga et al., 2018).

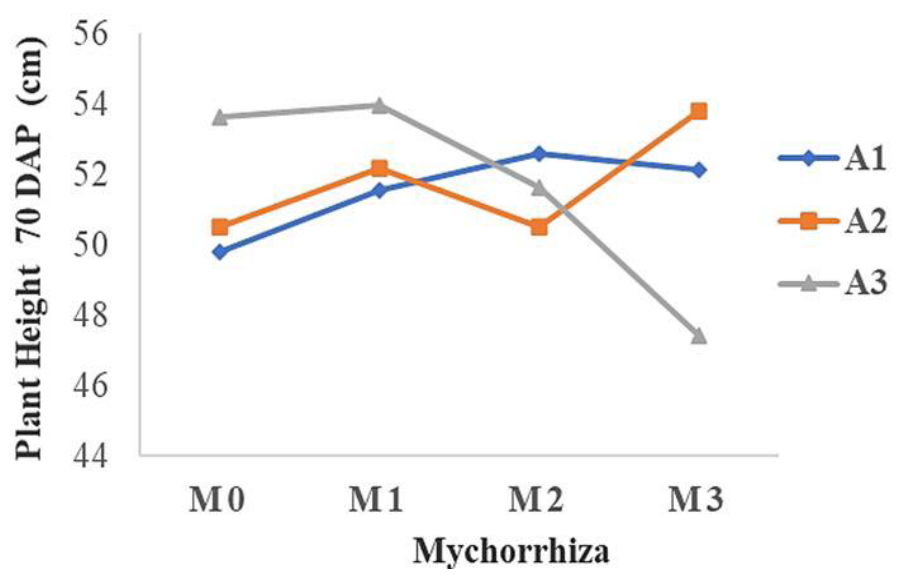

Figure 2: The interaction between the application of Rhizobium and mycorrbizae doses to plant height $70 \mathrm{~d}$ after planting.

Soaking the seeds before planting makes Rhizobium adaptable to the rhizosphere environment which makes it easier to develop and infect roots. If an application was continued by spraying encourages Rhizobium in the process of forming root nodules. Rhizobium plays a necessary role in $\mathrm{N}_{2}$-fixation from the atmosphere to form ammonium compounds (Sari and Prayudyaningsih, 2015). Most of the ammonium compounds that contain proteins will be converted into amino acids which then become the nitrogen compounds needed by plants for plant growth and development.

Figure 3 shows that the combination treatment of Rhizobium application by soaking and $20 \mathrm{~g}$ mycorrhizae (A1M3) produced the highest number of leaves 42.75. Double inoculation of Rhizobium with mycorrhizae has a synergistic effect on root nodule formation and nitrogen fixation, especially in $\mathrm{P}$ deficient soil. In this caused, element $\mathrm{P}$ is required for nodule formation and maximum nodule activity. Plants that get symbiotic nitrogen require more significant amounts of $\mathrm{P}$ than fertilized $\mathrm{N}$ plants (Haro et al., 2018; Jin et al., 2016). Therefore the administration of mycorrhizae greatly helps the absorption of $\mathrm{P}$ elements in the soil needed for plant development, including leaf formation and a number of branches.

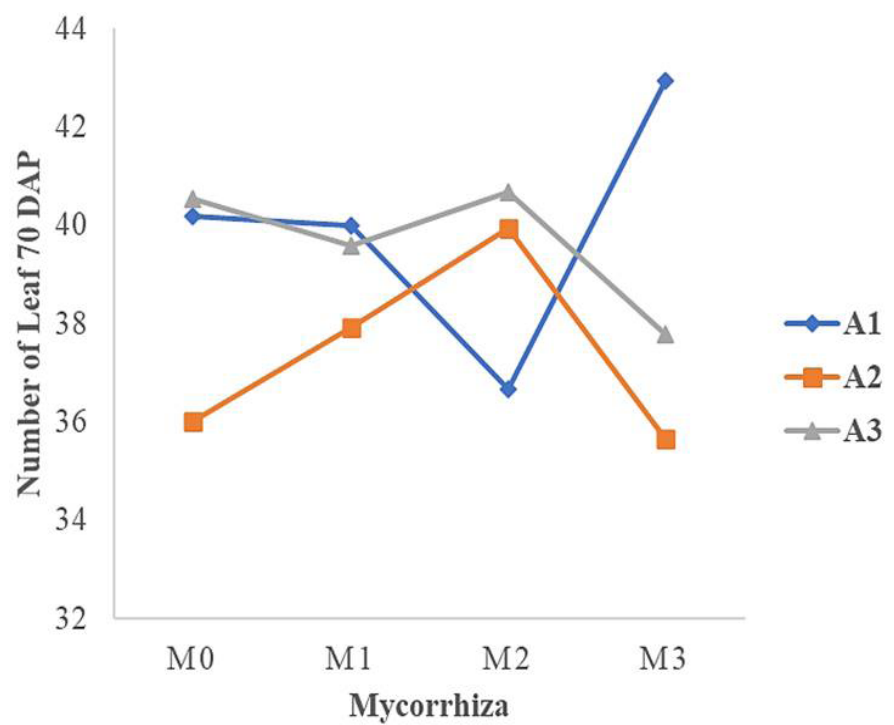

Figure 3: The interaction between the application of Rhizobium and mycorrbizae doses to number of leaf 70 $d$ after planting.

Table 4: Number of branches and Leaves Area Index of peanut plants as affected by Rhizobium application and doses of mycorrbizae.

\begin{tabular}{lccccccc}
$\begin{array}{l}\text { Treat- } \\
\text { ment }\end{array}$ & \multicolumn{5}{c}{ Number of branches } & & $\begin{array}{c}\text { Leaf area } \\
\text { index }\end{array}$ \\
& $\mathbf{1 4}$ dap & $\mathbf{2 8}$ dap & $\mathbf{4 2}$ dap & $\mathbf{5 6}$ dap & $\mathbf{7 0 ~ d a p}$ & $\mathbf{7 0 ~ d a p}$ \\
A1 & 2.07 & 6.43 & 6.77 & 8.78 & 8.90 & 7.0 \\
A2 & 2.07 & 6.42 & 6.70 & 8.23 & 8.38 & 6.9 \\
A3 & 2.20 & 6.73 & 7.05 & 8.42 & 8.53 & 7.6 \\
M0 & 2.11 & 6.51 & 6.82 & 8.67 & 8.77 & 6.1 \\
M1 & 2.22 & 6.51 & 6.89 & 8.80 & 8.95 & 7.4 \\
M2 & 2.02 & 6.64 & 6.84 & 8.11 & 8.27 & 7.6 \\
M3 & 2.09 & 6.44 & 6.80 & 8.33 & 8.42 & 7.5
\end{tabular}

The number of branches of peanut plants at all time of observation was not significantly affected by the application of Rhizobium or mycorrhizae doses, either in combination or individually, likewise for the leaf area index (Table 4). 
Although the effect of each factor was not significantly different on the number of branches, however, increase the most on the Rhizobium soak application (329.9\%), and without mycorrhizae (315.6\%). The increase in the number of branches will affect photosynthate transport from leaves to other parts of the plant for the better and have a positive impact on pod formation. But, the leaves will give its photosynthesis results, especially to pods in the same branch. The differences of the peanut's plant structure (main stem, types and the number of branches) determinate of pod number and pod weight on each structure (Giayetto et al., 2013).

The largest Leaf Area Index (LAI) was achieved by application of spray soak (A3) and a mycorrhizae dose of $10 \mathrm{~g}$ (M2) which is 7.6. The application of Rhizobium and mycorrhizae increased LAI by $75.12 \%$. Large LAI values will absorb more solar radiation and do the photolysis process of water. It is because the leaves are the main part of the plant that photosynthesis and produces assimilates. Photosynthetic activity is related to source capacity which is characterized by the growth rate of leaf area index, chlorophyll content, and stomata density (Purnamawati and Manshuri, 2015).

Table 5: Number of pods per plant on the Rbizobium application and various doses of mycorrbizae.

$\begin{array}{lc}\text { Treatment } & \text { Number of pods } \\ \text { A1 } & 21.92 \\ \text { A2 } & 22.62 \\ \text { A3 } & 24.45 \\ & \text { ns } \\ \text { M0 } & 21.69 \\ \text { M1 } & 23.60 \\ \text { M2 } & 22.49 \\ \text { M3 } & 24.24 \\ & n s \\ \end{array}$

\section{Production parameters}

The application of Rhizobium at various doses of mycorrhizae both in combination and independently did not significantly affect the number of pods per plant. The obtained result is tabulated in Table 5.

The number of pods per plant was not statistically significantly different in the application of Rhizobium, and mycorrhizae doses due to the peanut plants need more $\mathrm{Ca}$ (Phatak, 2010) than $\mathrm{N}$ elements or
$\mathrm{P}$ elements on pod formation phase. Ahmed et al. (2019) stated that there was a significant difference in the number of pods per plant in peanuts treated with microdoses of NPK. This shows that the number of pods per plant does not depend on the NPK element (Tian et al., 2019).

The data obtain that Rhizobium soaked spray (A3) and mycorrhizae doses of $20 \mathrm{~g}$ (M3) had the highest number of pods, 24.45 and 24.24, respectively. Calcium plays a role in promoting fertilization. Hence it is possible that calcium may exert an early effect on peanut reproduction by increasing the successful fertilization of the distal ovule, thereby increasing the number of pods. Whereas $\mathrm{P}$ serves to accelerate flowering and ripening of fruit and seeds, an element of $\mathrm{N}$ and $\mathrm{Ca}$ needed also when stage flowering.

There was a significant interaction between the application of Rhizobium at various doses of mycorrhizae to fresh pod weight (Fig. 4).

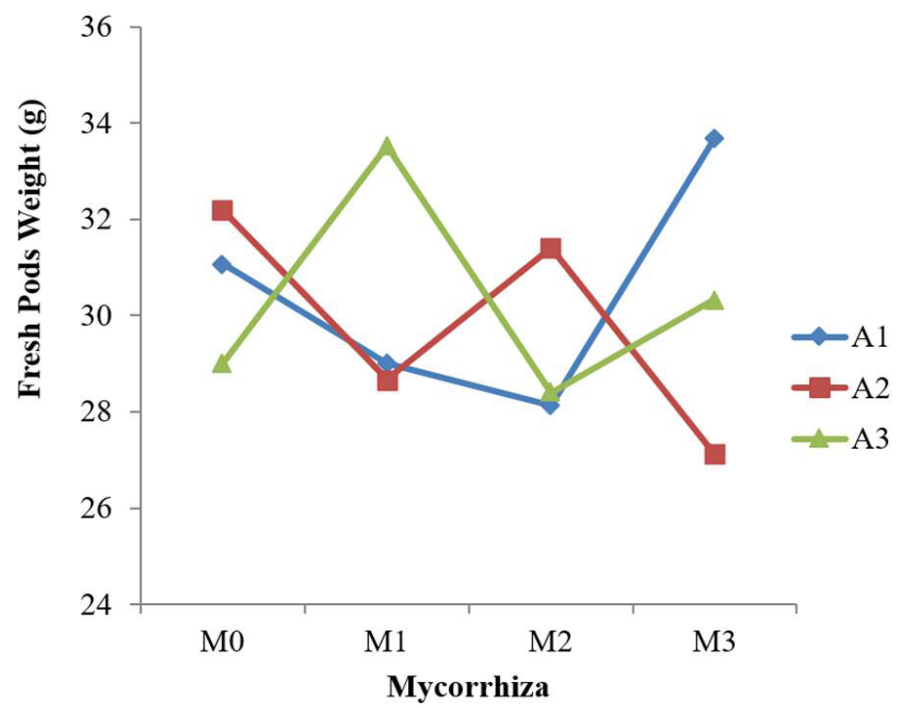

Figure 4: Effect of interaction between Rhizobium application and mycorrbizae doses to fresh pods weight per plant.

The analysis result reveals that soak Rhizobium applicated with $20 \mathrm{~g}$ mycorrhizae (A1M3) had the highest fresh pods weight per plant $(33.67 \mathrm{~g})$ although no different significant with combination treat between spray soak Rhizobium and $10 \mathrm{~g}$ mycorrhizae (A3M1) namely $33.53 \mathrm{~g}$. Based on the data in Table 4, two factors applied either in combination or individually did not affect the number of pods, so the number of pods did not determine the weight of the pod. An increase in the number of pods per plant is not always followed by filling pods (Al-Jobori and Al-Hadithy, 
2014). This is because at harvest not all pods are in the filling phase of the seeds, especially in pods that develop from flowers with the last anthesis process (Maji et al., 2017; Yaseen et al., 2016). The increasing number of pods per plant will disrupt the filling of previously formed pods, resulting in many unfill pods.

\section{Conclusions and Recommendations}

It is concluded that peanut should instead be grown with dual inoculation of mycorrhizae along with Rhizobium. The result showed that inoculation also exhibited a significantly positive response to the growth and yield of peanut. Mixed of mycorrhizal doses + Rhizobium application had increased NPK uptake. The dual inoculation of mycorrhizal doses and Rhizobium also enhanced root nodules of peanut plant indicating that their combination may have a potential role to improve the crop productivity.

Combine of the mycorrhizal doses and Rhizobium have a potential role in improving crop productivity by root nodule formation. It is also recommended to know the relation between NPK uptake and nodule formation, especially the effective root nodule.

\section{Novelty Statement}

Inoculation of peanuts with Rhizobium is mostly done using solid (granule) form inoculums. Meanwhile, the liquid rhizobium inoculum is rarely used and its application is sprayed on the soil during planting. Rhizobium needs time to adapt to environmental conditions for $\mathrm{N}_{2}$ fixation. Based on this, this study attempted to increase the effectiveness of $\mathrm{N}_{2}$ fixation, accelerate Rhizobium infection, and formation of root nodules by soaking the seeds combined with spraying to obtain the maximum number of pods. Vesicular Arbuscular Mychorizae is added along with the application of Rhizobium, to increase nitrogen uptake.

\section{Author's Contribution}

PGA and EDP conceived and designed the study, elaborated intellectual content, literature search, manuscript review and manuscript preparation. PGA and SR performed experimental studies. PGA acquired data, and performed data and statistical analysis.DDS, KS and RHS elaborated the intellectual content, literature search, manuscript preparation, and manuscript review. RHS performed manuscript editing and guarantor. All authors read and approved the final manuscript.

\section{Conflict of interest}

The authors declare that there is no conflict of interests regarding the publication of this article.

\section{References}

Abd-Alla, M.H., A.E. El-Enany, N.A. Nafady, D.M. Khalaf and F.M. Morsy. 2014. Synergistic interaction of Rhizobium leguminosarum bv.viciae and arbuscular mycorrhizal fungi as a plant growth promoting biofertilizers for faba bean (Viciafaba L.) in alkaline soil. Microbiol. Res., 169: 49-58. https://doi.org/10.1016/j. micres.2013.07.007

Adinurani, P.G., S. Rahayu, L.S. Budi, S. Pambudi and P. Soni. 2019. Production potential of sweet corn (Zea mays Linn. var. Saccharata Sturt) 'Bonanza' to different planting pattern and phosphorus sources. IOP Conf. Ser. EES, 293: 1-7. https://doi.org/10.1088/17551315/293/1/012032

Ahmed, Y.E.M., A.A.A. Osman, M.A. Makeen and T.E.A. Suliman. 2016. Effect of NPK micro doses fertilizer on leaf area, leaf area index and pods and hay yield of six genotypes of groundnut North Kordofan State Sudan. Int. J. Sci. Technol. Res., 5: 59-63.

Al-Jobori, K.M.M. and S.A. Al-Hadithy. 2014. Effect of seed soaking periods in varying levels of fertilizers on growth, yield and yield components of peanut. J. Agric. Crop Res., 2: 134-142.

Anteneh, A. 2017. Development of environmental friendly bioinoculate for peanut (Arachis bypogea L.) production in Eastern Ethiopia. Environ. Syst. Res., 6: 1-12. https://doi.org/10.1186/ s40068-017-0100-y

Bouznif, B., I. Guefrachi, R.C. Rodriquez de la Vega, M. Hungria, M. Mars, B. Alluni and J.A. Shykoff. 2019. Phylogeography of the Bradyrbizobium spp. associated with peanut, Arachis hypogaea: Fellow travelers or new associations? Front. Microbiol., 10: 1-13. https://doi.org/10.3389/fmicb.2019.02041

Budiono, R., P.G. Adinurani and P. Soni. 2019. Effect of new NPK fertilizer on lowland rice (Oryza sativa L.) growth. IOP Conf. Ser. EES, 
293: 1-10. https://doi.org/10.1088/17551315/293/1/012034

Chemining'wa, G.N., S.M.W. Theuri and Muthomi J. W. 2011. Abundance of indigenous rhizobia nodulating cowpea and common bean in Central Kenyan soils. J. Horticul. Sci. Biotechnol., 5: 92-97.

Giayetto, O., F.D. Morla, E.M. Fernandez, G.A. Cerioni, M. Kearney, M.B. Rosso and M.G. Violante. 2013. Temporal analysis of branches pod production in peanut (Arachis hypogaea) genotypes with different growth habits and branching patterns. Peanut Sci., 40: 8-14. https://doi.org/10.3146/PS12-10.1

Haro, H., K.B. Sanon, C. Le Roux, R. Duponnois and A.S. Traoré. 2018 Improvement of cowpea productivity by rhizobial and mycorrhizal inoculation in Burkina Faso. Symbiosis, 74: 107-120. https://doi.org/10.1007/s13199017-0478-3

Jin, Y., H. Liu, D. Luo, N. Yu, W. Dong, C. Wang, X. Zhang, H. Dai, J. Yang and E. Wang. 2016. DELLA proteins are common components of symbiotic rhizobial and mycorrhizal signalling pathways. Nat. Commun., 7: 12433. https:// doi.org/10.1038/ncomms12433

Kementerian Pertanian, 2017. Agricultural statistics. Pusat Data dan Sistem Informasi Pertanian.

Kukkamalla, K. and Z.N. Vardhan. 2016. A study on effective and ineffective root nodules of Trigonella Foenum Graecum Elicited by Bradyrhizobium. J. Environ. Sci. Toxicol., 10: 106-111.

Kurniaty, R., S. Bustomi and E. Widyawati. 2013. The usage of rhizobium and mycorrhizae on the growth of Kaliandra's seedling (Calliandra callothyrsus) at 5 month age. J. Perbenihan Tanaman Hutan, 2: 71-81.

Kurniawan, R.M., H. Purnamawati and Y.E.K. Wahyu. 2017. Growth respond and production of peanut (Arachis bypogaea L.) to deep furrow planting system and application of different fertilizers. Bull. Agrohorti, 5: 342-350. https:// doi.org/10.29244/agrob.v5i3.16472

Labidi, S., F. Ben Jeddi, B. Tisserant, M. Yousfi, M Sanaa, Y. Dalpé and S.A. Lounès-Hadj. 2015. Field application of mycorrhizal bioinoculants affects the mineral uptake of a forage legume (Hedysarum coronarium L.) on a highly calcareous soil. Mycorrhiza, 25: 297-309. https://doi.org/10.1007/s00572-014-0609-0

Malinda S.T., T. Chapagain, B. Ghimire, R. Pudasaini, B.B. Tamang, K. Gurung, K. Choi, L. Rai, S. Magar, B.K. Bishnu, S. Gaire and M.N. Raizada. 2019. Evaluating the effectiveness of rhizobium inoculants and micronutrients as technologies for Nepalese common bean smallholder farmers in the real-world context of highly variable hillside environments and indigenous farming practices. Agriculture, 9: 1-17. https://doi.org/10.3390/ agriculture 9010020

Maji, D., P. Misra, S. Singh and A. Kalra. 2017. Humic acid rich vermicompost promotes plant growth by improving microbial community structure of soil as well as root nodulation and mycorrhizal colonization in the roots of Pisum sativum. Appl. Soil Ecol., 110: 97-108. https:// doi.org/10.1016/j.apsoil.2016.10.008

Marzban, Z., E. Faryabi and S. Torabian. 2017. Effects of arbuscular mycorrhizal fungi and Rhizobium on ion content and root characteristics of green bean and maize under intercropping. Acta Agric. Slov., 109: 79-88. https://doi.org/10.14720/aas.2017.109.1.08

Meng, L., A. Zhang, F. Wang, X. Han, D. Wang and S. Li. 2015. Arbuscular mycorrhizal fungi and rhizobium facilitate nitrogen uptake and transfer in soybean/maize intercropping system. Front. P1. Sci., 6: 339. https://doi.org/10.3389/ fpls.2015.00339

Muhammad M., U. Isnatin, P. Soni and P.G. Adinurani. 2021. Effectiveness of mycorrhiza, plant growth promoting rhizobacteria and inorganic fertilizer on chlorophyll content in Glycine max (L.) cv. Detam-4 Prida. E3S Web Conf., 226: 1-8. https://doi.org/10.1051/ e3sconf/202122600031

Mukhongo, R.W., J.B. Tumuhairwe, P. Ebanyat, A.H. Abdel Gadir, M. Thuita and C. Masso. 2017. Combined application of biofertilizers and inorganic nutrients improves sweet potato yields. Front. Pl. Sci., 8: 219. https://doi. org/10.3389/fpls.2017.00219

Ortas, I. 2010. Effect of mycorrhiza application on plant growth and nutrient concentration in cucumber production under field conditions. Span. J. Agric. Res., 8: S116-S122. https://doi. org/10.5424/sjar/201008S1-1230

Pathak, B.P. 2010. Effect of calcium on peanut (Arachis Hypogaea L.) pod and seed development 
under field conditions. Thesis, University of Florida, USA.

Prayoga, D., M. Riniarti and Duryat. 2018. The application of rhizobium and urea on Paraserianthes falcataria seedling growth. J. Sylva Lestari, 6: 1-8. https://doi.org/10.23960/ js1161-8

Purbajanti, E.D., P.G. Adinurani, T. Turkadze, Z. Vincēviča-Gaile and R.H. Setyobudi. 2019. Effectiveness the source of nitrogen from $\mathrm{NO}_{3}$ and $\mathrm{NH}_{4}$ for Panicum maximum Jacq. growth in saline soil.IOP Conf.Ser.EES,293:1-7.https:// doi.org/10.1088/1755-1315/293/1/012015

Purnamawati, H. and A.G. Manshuri.2015. Source and sink in peanut plants. Monograf Balitkabi, 13: 84-93.

Rehman, R., Z. Ahmad, W. Ahmad, M. Mansoor and S. Masaud. 2019. Efficacy of different rhizobium strains on nodulation and seed yield in mungbean (Vegna radiata L.) cultivar "Inqalab Mung". Sarhad J. Agric., 35(4): 1099-1106. https://doi.org/10.17582/journal. sja/2019/35.4.1099.1106

Sari, R. and R. Prayudyaningsih. 2015. Rhizobium: Utilization as nitrogen-fixing bacteria. J. Info Teknis Eboni, 12: 51-64.

Simonsen, A.K., R. Dinnage, L.G. Barrett, S.M. Prober and P.H. Thrall. 2017. Symbiosis limits establishment of legumes outside their native range at a global scale. Nat. Commun., 8: 1-9. https://doi.org/10.1038/ncomms14790

Sukmawati, S., A. Adnyana, D.N. Suprapta, M. Proborini, P. Soni and P.G. Adinurani. 2021. Multiplication arbuscular mycorrhizal fungi in corn (Zea mays L.) with pots culture at greenhouse. E3S Web Conf., 226:1-10.https:// doi.org/10.1051/e3sconf/202122600044

Suryantini. 2015. Nitrogen nodulation and fixing in peanut plants. Monograf Balitkabi, 13: 234250.

Sumarno. 2015. Peanut status in Indonesia. Monograf Balitkabi, 13: 29-39.

Tian, H., M. Kah and K. Kariman. 2019. Are nanoparticles a threat to mycorrhizal and rhizobial symbioses? A critical review. Front. Microbiol., 10: 1660. https://doi.org/10.3389/ fmicb.2019.01660

Taurian, T., F. Ibanfiez,, A. Fabra, and O.M. Aguilar. 2006. Genetic diversity of rhizobia nodulating Arachis hypogaea L. in Central Argentina soils. Plant Soil, 282: 41-52.https://doi.org/10.1007/ s11104-005-5314-5

Utami, S.N.H., A.M. Abduh, E. Hanudin and B.H. Purwanto. 2020. Study on the NPK uptake and growth of rice under two different cropping systems with different doses of organic fertilizer in the Imogiri Subdistrict, Yogyakarta province, Indonesia. Sarhad J. Agric. 36(4): 1190-1202. https://doi.org/10.17582/journal. sja/2020/36.4.1190.1202

Yakubu, H., J.D. Kwari and M.K. Sandabe. 2010. Effect of phosphorus fertilizer on nitrogen fixation by some grain legume varieties in Sudan -Sahelian Zone of North Eastern Nigeria. Nig. J. Basic Appl. Sci., 18: 19-26. https://doi. org/10.4314/njbas.v18i1.56837

Yaseen, T., K. Ali, F. Munsif, A. Rab, M. Ahmad, M. Israr and A.K. Baraich. 2016. Influence of arbuscular mycorrhizal fungi, rhizobium inoculation and rock phosphate on growth and quality of lentil. Pak. J. Bot., 48: 2101-2107. 